\title{
CODE-SWITCHING AND CODE-MIXING USED BY GUEST STAR IN HOTMAN PARIS SHOW
}

\author{
Maya Sari $^{1}$, Adip Arifin ${ }^{2}$, Ratri Harida ${ }^{3}$ \\ ${ }^{123}$ English Language Education Department, STKIP PGRI Ponorogo \\ ${ }^{1}$ mayasari3766@gmail.com, ${ }^{2}$ adiparifin@yahoo.com, ${ }^{3}$ ratri3rida@gmail.com
}

\begin{abstract}
Code-switching and code-mixing are the linguistic phenomena that commonly occur in bilingualism society. Code-switching happens when the speakers mix words or phrases from the two languages during the course of speech or conversation. Meanwhile, code-mixing is the change of one language to another within the same utterance or in the same oral or written text. This research aimed to find out the types of code-switching, code-mixing and the reason as well used by Cinta Laura Kiehl as the guest star in Hotman Paris Show television program on January $2^{\text {nd }} 2020$. This research also aimed to find out the reason of Cinta Laura Kiehl of doing code-switching and code-mixing. The researcher used descriptive qualitative method as the research design. Content analysis and documentation was used as the technique to collect the data. The instruments used were human instrument and documentation sheet. To analyze the data, the researcher used Miles and Huberman (1994) interactive model. The result of the research showed that all the types of code-switching and code-mixing was used by Cinta Laura Kiehl. The most dominant type of code-switching used was intra-sentential code-switching and the most dominant type of code-mixing used was insertion. The most dominant reason of doing code-switching and code-mixing used was to maintain talking about a particular topic.
\end{abstract}

Keywords: Bilingualism, Code-Switching, Code-Mixing, Hotman Paris Show

\section{INTRODUCTION}

Realized or not, people now live in the world of bilingualism. In today's era, it is very rare to find out a monolingual society. Indonesia in this case, also has been a part of bilingualisms. Most of Indonesian people speak up at least using two languages. They speak their local language and Bahasa Indonesia as their second language. In practice, bilingualism in Indonesia does not only occur within local language and Bahasa Indonesia, but also between Bahasa Indonesia and foreign language. Ningrum and Harida (2021: 45) emphasized that the bilingualism requires both language use and mastery in the same time. Further, Arifin (2018) characterized that the form of language use can be various, both in spoken or written form, such as informal conversation, dialogue, spoken/written text, presentation, speech, etc. In line with Arifin, Herdiawan and Arifin (2017) highlighted that the bilingualism is something in common today, and it has colored Indonesians' life. 
In Indonesia, English is acknowledged as foreign language which used in quite limited context. The situation triggers many Indonesians to speak bilingual. Herdiawan (2017) points out that bilingualism is a progressive aid that can be employed to improve the speaker' cognition as well as linguistic competence. Therefore, Indonesians often switch and mix the code (language) while speaking. In language study, the phenomena are recognized as codeswitching and code-mixing. Code-switching is language phenomenon when there are two or more languages live in a community and it makes speakers frequently switch from one language to another language (Hornberger and McKay, 2010; Fransiska and Arifin, 2021).

In bi- and multilingual speech communities, code-switching is a linguistic phenomenon that commonly occurs (Mahootian, 2006). Wardaugh (2006) described whenever people choose to speak; they required selecting a particular code. Sometimes, they may also have to switch from one code to another or mix codes even within a very short utterance. Thereby, new code will be created. In language study, this process of creating new code is known as codeswitching. Further, for the sake of language teaching, Suprayitno et al (2019) strongly suggested that the activities of language learning are ideally realized to equip learners with necessary competences and good manner for various given contexts.

According to Poplack (1980), code-switching can be identified in three types; tag-switching, intra-sentential code-switching, and inter-sentential code-switching. Tag-switching involves a situation in which a bilingual attaches a tag from one language to an utterance in another language. A tag from one language is otherwise entirely in the other language, e.g. you know, I mean, Darn!, Hey!, Well!, Look!, etc. Intra-sentential code-switching happens when the alternation of language used is below sentential boundaries. Inter-sentential code-switching involves a switch from a clause or sentence boundary, where each clause or sentence is in one language or another between speaker turns (Romaine, 2000).

Meanwhile, code-mixing is the change of one language to another language within the same utterance or in the same oral or written text (Nababan, 1993). Risdianto (2003) explained that code-mixing as the transition from using linguistic units (word, phrase, clause, etc) of one language to use those of another within a single sentence. While Bokamba (1988) stated code-mixing coincides with intra-sentential code-switching. Intra-sentential code-switching happens when the alternation of the language used is below sentential boundaries.

Muysken (2000) described that code-mixing is typically divided into three main types; insertion, alternation, and congruent lexicalization. Insertion is code-mixing process which is conceived as something similar to borrowing. Alternation means that the alternation between a structure from a language. It is used when the speakers mix the language with a phrase. The last is congruent lexicalization of material from different lexical inventories into a shared grammatical structure, where two languages share grammatical structure, which can be filled lexically with elements from either language. In practice, Kartika et al (2020: 297) highlighted that the realization of code mixing and code switching appears in various forms, such as oral and written communication, face to face communication, online communication, and so forth.

This study will investigate code-switching and code-mixing performed by one of Indonesian celebrities that is Cinta Laura Kiehl. The aims of the study are to find out what types of codeswitching and code-mixing used by Cinta Laura Kiehl in Hotman Paris Show and to explain the reasons of Cinta Laura Kiehl did code-switching and code-mixing. This study is expected to provide information needed for everyone studying code-switching and code-mixing. For English language teachers, this research will bring awareness on the essentials of code- 
switching and code-mixing. For students, this research is expected to help them consider between the advantages of pure English from that code-switching and code-mixing.

\section{METHOD}

The researcher uses descriptive qualitative method and designed as library research. The object of the research is the utterances produced by Cinta Laura Kiehl in Hotman Paris Show on January $2^{\text {nd }} 2020$ which contains Indonesian-English code-switching and code-mixing. The researcher does the research by doing the following steps: (1) searching the video of Cinta Laura Kiehl on Youtube to be selected, (2) watching and listening to the video, (3) transcribing the utterances containing code-switching and code-mixing, (4) classifying the utterances by the types code-switching and code-mixing, (5) analyzing the reason of doing code-switching and code-mixing, (6) concluding the data. The researcher uses content analysis and documentation as the techniques of collecting data. This study uses Miles and Huberman (1994) interactive model to analyze the data.

\section{FINDINGS AND DISCUSSION}

The findings of this research showed that Cinta Laura Kiehl performed all the types of codeswitching and code-mixing. There were two reasons that Cinta did not perform in the whole show. They were quoting somebody else and expressing group identity. The switched segments of Bahasa Indonesia-English code-switching, code-mixing, and reason of doing were shown in the table below.

\section{Findings}

Table 1: The Findings of Code-Switching

\begin{tabular}{llll} 
No. Utterances & $\begin{array}{l}\text { Types of Code- } \\
\text { Switching }\end{array}$ & Time \\
\hline 1. & Apa kabar? How are you? & Tag-switching & 03.42 \\
\hline 2. & Yes, itu bener. & Tag-switching & 09.41 \\
\hline 3. & Of course, actually bang Hotman. & Tag-switching & 11.11 \\
\hline 4. & $\begin{array}{l}\text { Aku pertama ke Amerika karna sekolah di } \\
\text { Columbia University and everybody knows } \\
\text { that. }\end{array}$ & 07.22 \\
\hline $\begin{array}{l}\text { Aku berusaha lewat karya aku untuk menjadi } \\
\text { role model yang positif. }\end{array}$ & Intra-sentential & 10.13 \\
\hline 6. & $\begin{array}{l}\text { Kalau misalnya ada dosa apapun itu aku gak } \\
\text { bisa nge- judge karna aku bukan Tuhan. }\end{array}$ & Intra-sentential & 13.47 \\
\hline 7. & $\begin{array}{l}\text { I think mungkin setiap orang jawabnnya } \\
\text { akan beda ya. }\end{array}$ & Intra-sentential & 14.36 \\
\hline 8. & $\begin{array}{l}\text { Aku satu-satunya orang yang bukan orang } \\
\text { Latin. So that was really cool. }\end{array}$ & Inter-sentential & 06.17 \\
\hline 9. & $\begin{array}{l}\text { They tought I was Latin. Tapi aku bilang aku } \\
\text { bukan orang Latin. }\end{array}$ & Inter-sentential & 06.22 \\
\hline 10. & $\begin{array}{l}\text { I am an independent woman. Aku gak perlu } \\
\text { uang dari siapapun. }\end{array}$ & Inter-sentential & 14.44 \\
\end{tabular}


Here Cinta switched the language ten times. All the types of code-switching were used by her. Intra-sentential code-switching was the types of code-switching she mostly used.

Table 2: The Findings of Code-Mixing

\begin{tabular}{|c|c|c|c|}
\hline No. & Utterances & $\begin{array}{l}\text { Types of Code- } \\
\text { Mixing }\end{array}$ & Time \\
\hline 1. & $\begin{array}{l}\text { Menurut aku sekarang mindset- nya harus } \\
\text { mulai dirubah. }\end{array}$ & Insertion & 05.05 \\
\hline 2. & Tapi please jangan misunderstand $a k u$ ya. & Insertion & 08.04 \\
\hline 3. & $\begin{array}{l}\text { Aku bisa ngelihat progress yang baik dalam } \\
\text { karir aku di luar sana. }\end{array}$ & Insertion & 08.12 \\
\hline 4. & $\begin{array}{l}\text { Aku berusaha lewat karya aku untuk menjadi } \\
\text { role model yang positif. }\end{array}$ & Insertion & 10.13 \\
\hline 5. & $\begin{array}{l}\text { Kalau ada korban kekerasan apalagi } \\
\text { perempuan di Amerika, mereka dikasih } \\
\text { lawyer gratis, fasilitas gratis, mau itu } \\
\text { rehabilitasi physical atau mental apapun itu } \\
\text { semua fasilitas gratis. }\end{array}$ & Insertion & 11.24 \\
\hline 6. & $\begin{array}{l}\text { I think mungkin setiap orang jawabannya } \\
\text { akan beda ya. }\end{array}$ & Insertion & 14.36 \\
\hline 7. & $\begin{array}{l}\text { Jadi kolaborasi dengan HBO Amerika and I } \\
\text { won best actress in a whole film. }\end{array}$ & Alternation & 06.07 \\
\hline 8. & $\begin{array}{l}\text { Aku pertama ke Amerika karna sekolah di } \\
\text { Columbia University and everybody knows } \\
\text { that. }\end{array}$ & Alternation & 07.22 \\
\hline 9. & $\begin{array}{l}\text { Aku bukan bilang "Oh, I am a big Hollywood } \\
\text { star." }\end{array}$ & Alternation & 08.09 \\
\hline 10. & You are very caliente today. & $\begin{array}{l}\text { Congrnt } \\
\text { Lexicalization }\end{array}$ & 16.04 \\
\hline
\end{tabular}

Here Cinta mixed the language ten times. All the types of code-mixing were used by her. Insertion was the type of code-mixing she mostly used. She used insertion of word four times and insertion of phrase two times. Congruent lexicalization only used by her one time in the whole show.

Table 3: Reasons of Doing Code-Switching and Code-Mixing

No. Utterances Reasons of Doing

1. Kalo kita nonton Netflix, banyak tv series dan Talking about a particular film-filmnya gak Cuma dari Amerika aja, topic dari Indonesiapun ada.

2. Aku pertama ke Amerika karna sekolah di Talking about a particular Columbia University and everybody knows topic that.

3. Kebetulan aku dikenalin dengan salah satu Talking about a particular management yang bagus disana yang ngasih topic. aku opportunity buat casting banyak sekali 
project - project besar.

\begin{tabular}{|c|c|c|}
\hline 4. & $\begin{array}{l}\text { Menurut aku juga penting sekali sebagai } \\
\text { entertainer Indonesia, kita juga gak ngelupain } \\
\text { Indonesia dan terus berkarya disini juga. }\end{array}$ & $\begin{array}{l}\text { Talking about a particular } \\
\text { topic }\end{array}$ \\
\hline 5. & $\begin{array}{l}\text { Aku satu - satunya orang yang bukan orang } \\
\text { Latin. So that was really cool. }\end{array}$ & $\begin{array}{l}\text { Talking about a particular } \\
\text { topic and interjection } \\
\text { (inserting sentence fillers or } \\
\text { sentence connector) }\end{array}$ \\
\hline 6. & $\begin{array}{l}\text { Cara go international bukan hanya dengan } \\
\text { meng- import artis-artis kita ke LA atau ke } \\
\text { Hollywood. }\end{array}$ & $\begin{array}{l}\text { Talking about a particular } \\
\text { topic and intention of } \\
\text { clarifying speech content for } \\
\text { interlocutor }\end{array}$ \\
\hline 7. & Yes, itu bener. & $\begin{array}{lll}\begin{array}{l}\text { Repetition } \\
\text { clarification }\end{array} & \text { used for } \\
\end{array}$ \\
\hline 8. & It's good to be back. It's my second time here. & $\begin{array}{l}\text { Showing empathy about } \\
\text { something }\end{array}$ \\
\hline 9. & Apa kabar? How are you? & $\begin{array}{l}\text { Repetition used for } \\
\text { clarification and showing } \\
\text { empathy about something }\end{array}$ \\
\hline 10. & Please jangan misunderstand $a k u$ ya. & $\begin{array}{l}\text { Intention of clarifying speech } \\
\text { content for interlocutor }\end{array}$ \\
\hline 11. & $\begin{array}{l}\text { Aku bukan bilang "Oh, I am a big Hollywood } \\
\text { star." }\end{array}$ & $\begin{array}{l}\text { Intention of clarifying speech } \\
\text { content for interlocutor }\end{array}$ \\
\hline 12. & I am sorry. I am not trying & $\begin{array}{l}\text { Intention of clarifying speech } \\
\text { content for interlocutor }\end{array}$ \\
\hline
\end{tabular}

The most frequent reason used by Cinta was talking about a particular topic. Sometimes, she used more than one reason. The most often double reasons used by Cinta was when it combined with talking about a particular topic. The second most frequent reason used by Cinta was intention of clarifying the speech content for interlocutor.

\section{Discussion}

The types of code-switching Cinta mostly used was intra-sentential code-switching. In table 1, it represented on number 4 until 7. The discussion of the findings is presented below:

"Aku pertama ke Amerika karna sekolah di Columbia University and everybody knows that."

First, Cinta used Bahasa Indonesia "Aku pertama ke Amerika karna sekolah di Columbia University" then she switched into English "and everybody knows that". In the next sentence; "Aku berusaha lewat karya aku untuk menjadi role model yang positif." Cinta inserted the phrase "role model" in the middle of her sentence. She mostly used Bahasa Indonesia in the sentence. In this case, the intra-sentential-switching is identified. Another intra-sententialswitching also can be identified in the following findings: "Kalau misalnya ada dosa apapun itu aku gak bisa nge- judge karna aku bukan Tuhan." Cinta mostly used Bahasa Indonesia in the sentence. She only inserted the word "judge" in the middle of her sentence.

"I think mungkin setiap orang jawabnnya akan beda ya." Cinta began her sentence with English with inserting the phrase "I think" and finishing it with Bahasa Indonesia. All the 
sentences indicate intra-sentential code-switching where, a shift was done in clause or sentence boundaries. One phrase or one clause being in one language, while the other phrase or clause using another type of language. Cinta's proficiency in two languages make it easy for her to switch from one language to another.

The second type of-switching Cinta mostly used was inter-sentential code-switching. It represented on number 8 up to 10. Can be seen in the following sentence; "Aku satu-satunya orang yang bukan orang Latin. So that was really cool." The first sentence Cinta used was Bahasa Indonesia "Aku satu-satunya orang yang bukan orang Latin". Then, she switched to English "So that was really cool".

"They tought I was Latin. Tapi aku bilang aku bukan orang Latin." Otherwise, Cinta used English "They thought I was Latin" in the first sentence and then switched it into Bahasa Indonesia "Tapi aku bilang aku bukan orang Latin", and then continued; "I am an independent woman. Aku gak perlu uang dari siapapun." The first sentence was English then it followed by Bahasa Indonesia.

After finishing one sentence in one type of language, Cinta switched into another type of language to make a new sentence. The shift of two languages was done between the sentences. So that all the three sentences categorized as inter-sentential code-switching. Cinta's proficiency in two languages make it easy for her to switch from one language to another. The types of code-mixing Cinta mostly used was insertion. In table 2, it represented on number 1 until 6.

"Menurut aku sekarang mindset- nya harus mulai dirubah." Cinta inserted the word "mindset". It means that she used the types of code-mixing that is insertion of word. She mostly used Bahasa Indonesia in the sentence. Just like the previous, the followings are the findings on inter-sentential code-switching; "Tapi please jangan misunderstand aku ya." Cinta inserted the word "please" and "misunderstand". It also indicates the use of codemixing that is insertion of word. The next sentence; "Aku bisa ngelihat progress yang baik dalam karir aku di luar sana." Cinta mostly used Bahasa Indonesia in the sentence. She only inserted the word "progress" in the whole sentence. More evidences on inter-sentential codeswitching can be observed in the following sentence; "Aku berusaha lewat karya aku untuk menjadi role model yang positif." The type of code-mixing that Cinta used was insertion of phrase. She inserted the phrase "role model" in the sentence. The next; "Kalau ada korban kekerasan apalagi perempuan di Amerika, mereka dikasih lawyer gratis, fasilitas gratis, mau itu rehabilitasi physical atau mental apapun itu semua fasilitas gratis." The type of codemixing that Cinta used was insertion of word. She inserted the word "lawyer", "physical", and "mental" in the sentence. The last finding on insertion is; I think mungkin setiap orang jawabannya akan beda ya. Cinta inserted the phrase "I think" in the sentence. The type of code-mixing that she used was insertion of phrase.

Based on the findings, there were four sentences indicate insertion of word and two sentences indicate insertion of phrase. In code-mixing, insertion happen when someone inserts the word or phrase from another language into a particular type of language during one sentence.

The second type of code-mixing Cinta mostly used was alternation. It represented on number 7 up to 9. It can be seen in the following evidences; "Jadi kolaborasi dengan HBO Amerika and I won best actress in a whole film." There were two clauses in the sentences. The first clause was "Jadi kolaborasi dengan HBO Amerika". And the second clause was "and I won best actress in a whole film". The next sentence; "Aku pertama ke Amerika karna sekolah di Columbia University and everybody knows that." The first clause was "Aku pertama ke 
Amerika karna sekolah di Columbia University". And the second clause was "and everybody knows that".

"Aku bukan bilang "Oh, I am a big Hollywood star." The alternation happened when Cinta said "Oh, I am a big Hollywood star."

All the three sentences were categorized as the alternation of code-mixing. The alternation happened when the speaker switched the language within one sentence and the switch of language is in the form of a clause.

Whether it is the insertion or alternation both are also categorized as intra-sentential codeswitching. According to Bokamba (1988) code-mixing coincides with intra-sentential codeswitching. Intra-sentential code-switching happens when the alternation of the language used is below sentential boundaries. Both code-switching and code-mixing are defined as the switch of language during the conversation. The difference is that code-switching can happen within the sentence or between the sentences and code-mixing only happen within the sentence. The switch of language in code-mixing happens in sentence boundary. It can be concluded that code-mixing is a part of code-switching that is intra-sentential code-switching.

\section{CONCLUSION}

The most dominant type of code-switching used by Cinta Laura Kiehl was intra-sentential code-switching. Meanwhile, the most dominant type of code-mixing used by Cinta Laura Kiehl was insertion. There are seven reasons of doing code-switching according to Hoffman (1991). From those reasons, Cinta Laura Kiehl performed five of them. The most dominant reason of doing code-switching performed by Cinta Laura Kiehl was talking about a particular topic.

\section{REFERENCES}

Arifin, A. (2018). How Non-native Writers Realize their Interpersonal Meaning? Lingua Cultura, vol. 12 (2), pp. 155-161. Retrieved online from https://journal.binus.ac.id/index.php/Lingua/article/view/3729

Bokamba, E. (1988). Code-Mixing and Grammatical Theory: A Cross- Linguistic Study. Paper Presented at the $21^{\text {st }}$ Chicago Linguistic Society Meeting, University of Chicago.

Fransiska, A. W. and Arifin, A. (2021). Analysis of Translation Techniques on the English Teachers' Translation of English Articles. Salience, vol. 1 (1), pp. 9-17. Retrieved online

from https://jurnal.lppmstkipponorogo.ac.id/index.php/Salience/article/view/10/16

Herdiawan, R. D. (2017). The Contributive Roles of Bilingualism in English Language Teaching. Journal of English Language Learning, vol. 1(1). Retrieved online from http://jurnal.unma.ac.id/index.php/JELL/article/view/874/867

Herdiawan, R. D. and Arifin, A. (2017). The Development of Students' Literacy Skills through Social Media as Popular Culture. Proceedings: The $1^{\text {st }}$ International Conference on Linguistics and English Teaching: Swadaya Gunung Jati University.

Hoffman, C. (1991). An Introduction to Bilingualism. London: Longman. 
Hornberger, N. H. and McKay, S. L. (2010). Sociolinguistics and Language Education. Bristol: Short Run Press.

Kartika, S. N., Harida, R. and Arifin, A. (2020). Code Mixing and Code Switching Found in Video Instagram. Deiksis, vol. 12(3), pp. 296-306. Retrieved online from https://journal.lppmunindra.ac.id/index.php/Deiksis/article/view/5583

Mahootian, S. (2006). Code Switching and Mixing. in K. Brown (Ed.), Encyclopedia of Language \& Linguistics. Oxford: Elsevier.

Miles, M. B. and Huberman, A. M. (1994). An Expanded Sourcebook: Qualitative Data Analysis Second Edition. Thousand Oaks: SAGE Publications, Inc.

Muysken, P. (2000). Bilingual Speech: A Typology of Code-Mixing. Cambridge: Cambridge University Press.

Nababan, P. W. J. (1993). Sociolinguistics: Sebuah Pengantar. Jakarta: Gramedia Pustaka.

Ningrum, A. C. K. and Harida, R. (2021). Code Switching in Teaching Narrative for Junior High School. Salience, vol. 1(1), pp 44-52. Retrieved online from https://jurnal.lppmstkipponorogo.ac.id/index.php/Salience/article/view/14

Poplack, S. (1980). Soetimes I'll Start a Sentence in Spanish y Termino en Español. Linguistics, pp. 581-618, Vol 18.

Risdianto, F. (2003). An Introduction of Sociolinguistic. Salatiga: STAIN Salatiga Press.

Romaine, S. (2000). Language in Society: An Introduction to Sociolinguistics. Oxford: Oxford University Press.

Suprayitno, E., Rois, S. and Arifin, A. (2019). Character Value: The Neglected Hidden Curriculum in Indonesian EFL Context. Asian EFL Journal, vol. 23 (3.3), pp. 212229. Retrieved online form https://www.asian-efl-journal.com

Wardhaugh, R. (2006). An Introduction to Sociolinguistics. Oxford: Blackwell Publishing. 